\title{
Сравнительный анализ морфологических признаков гранул крахмала Solanum tuberosum из растений, выращенных в 2016-2017 годах
}

\author{
Т.В. Эрст*, А.В. Дорошков, В.К. Хлесткин \\ ФИЦ Институт ичитологии и генетики СО РАН, Новосибирск, Россия \\ *e-mail: erst@bionet.nsc.ru
}

Картофель представляет собой одну из наиболее возделываемых сельскохозяйственных культур в мире. В качестве сырья для промышленного применения картофель - легкодоступный в извлечении и переработке, недорогой источник крахмала. Гранулы крахмала различной сортовой принадлежности имеют различные проявления фенотипических признаков, оптимальные для тех или иных технологических задач. Предположительно, генотип вносит значительный вклад в морфологические признаки гранул крахмала. Известно много примеров влияния генетических модификаций картофеля на размер и форму гранул. Несмотря на то что гены биосинтеза картофельного крахмала хорошо изучены и отсеквенированы, эффекты различных комбинаций аллельных вариаций этих генов на морфологию гранул крахмала не очевидны.

Целью данной работы является фенотипирование коллекции картофеля ФИЦ ИЦиГ СО РАН по морфологическим признакам и идентификация сортов с контрастными значениями этих признаков, а также поиск ассоциированных с ними аллелей генов биосинтеза крахмала.

С помощью световой микроскопии получены данные по семи морфологическим параметрам, таким как площадь проекции гранулы в кадре, соотношение площади к наибольшему диаметру, соотношение площади к выпуклой области, округлость, наибольший и наименьший диаметр частицы, их соотношения.

В работе анализируются данные по морфологическим параметрам гранул крахмала, полученных из растений урожая 2016 и 2017 гг. С помощью метода главных компонент, во-первых, показана сортовая кластеризация, во-вторых, удалось показать наличие генетического вклада в формирование морфологических признаков и идентифицированы сорта, наиболее отзывчивые на условия окружающей среды по этим признакам.

Выявление закономерностей между генотипом и фенотипом позволит подбирать и использовать молекулярные маркеры с целью ускоренного создания новых сортов с требующимися значениями практически важных признаков.

Благодарности: Работа выполнена при финансовой поддержке РФФИ (проект № 17-44-540510). Образцы картофеля получены из коллекции ЦКП «ГенАгро» ИЦиГ СО РАН. 